\title{
Political Willingness to Implement Public Sector Financial Management Reforms in Ghana - Accrual Basis of Accounting
}

\author{
Julius Aidoo-Buameh ${ }^{1}$ \\ ${ }^{1}$ Central Business School, Central University College, Accra, Ghana \\ Correspondence: Julius Aidoo-Buameh, Central Business School, Central University College, Accra, Ghana. E-mail: \\ jabuameh@central.edu.gh or jaidoo31@yahoo.co.uk \\ Received: January 24, 2014 \\ Accepted: February 13, 2014 \\ Online Published: February 17, 2014 \\ doi:10.5430/afr.v3n1p96 \\ URL: http://dx.doi.org/10.5430/afr.v3n1p96
}

\begin{abstract}
Public Sector Financial Management (PSFM) reforms are introduced to Public Sectors to improve upon probity, transparency, accountability and good governance. Though, usually initiated by various bodies or stakeholders other than the government, PSFMs are worldwide implementable by governments. More so when such reforms are aimed at fighting fraud, misappropriation, and corruption; governments' commitment to implementing these reform projects is believed to be inextricable from their Political Will to that respect. The study picks reform from Cash Basis to Accrual Accounting system, one of such widely noted reforms to determine the effect of governments' commitment to this cause, and its effects thereof, using the fisher exact model. It concludes that, cash basis creates distortions in PSFM systems, and is vulnerable to financial abuse, fraud, and embezzlements and yet, the implementation of the accrual basis, an acknowledged superior alternative continues to linger on due to absence of Political Will on the part of government to exact the project, thus, confirming the effect POLITICAL WILL has on PSFM reform implementations.
\end{abstract}

Keywords: PSFM, Reform, Cash basis, Accrual basis, Political Will, Fraud

\section{Introduction}

\subsection{General Introduction}

In recent years, governments and regulatory bodies worldwide appear to have intensified measures to ensure improved record keeping systems modelled in accordance with acceptable accounting practices and standards. The quest for this improvement has inspired an international movement of New Public Management from cash to accrual accounting systems across countries worldwide (Tiron Tudor \& Mutiu, 2013). One of such moves initiated through strong engagements with IFAC-PSC chair was intended to deal with the increased diversification of accounting systems; quality of government reports; and, interest of international finance institutions, all in the bid of making public accounts more reliable.

Undoubtedly, the reliability of the accounts depends on how true and fair the records are perceived to reflect the reality on the ground. Anything short of that serves as recipe for failure and poor performance in driving accountability and transparency.

The reliability of government reporting and transparency having been severally questioned, makes it more critical than ever for Public Sector institutions to build trust. In the case of Ghana, concerns raised at Public Accounts Committee hearings are a testimony to that effect. Manifest in several countries worldwide, the International Public Sector Accounting Standards Board (IPSASB) recommended reforms including improvements to cash accounting systems in Public Sector financial reporting to assure proper accountability and monitoring.

According to Kpundeh (date unknown), lessons learned from successful reform programmes across the world suggests need for strong Political Will, demonstrated by commitment from leadership (Kpundeh, year unknown). Such Political Will, she explains, can reside in many locations including all branches of government, international organisations; and, in both public and private sector institutions, thus, if reforms should be systemic and must have both macro and micro level interventions (Kpundeh, year unknown). 


\subsection{Specific Problem Statement}

In Ghana, in spite of the Financial Administrative Regulations (FAR), 2004 (L.I. 1802, Part VII, 186 requiring government accounts to be prepared using the Accrual basis of accounting (Government of Ghana, 2004), almost ten years into time, most organisations in the Public Sector continue to run the cash basis accounting system.

Unfortunately, the cash basis of accounting is acknowledged as lacking the edge for providing proper measurement of performance, and records economic events not when they occur, but only when cash is paid in or out (Tiron Tudor \& Mutiu, 2013; Accounting Technicians Schemes of West Africa, 2013). With same method of accounting, there are difficulties in measuring physical work produced in contrast with assets consumed within a defined period, as the technique does not recognise the time when resources are used. In other words, the cash basis accounting systems leave gabs between economic event and actual cash payment unrecorded or not recognised in the books of accounts. Financial statements prepared based on Cash basis neither reflect information about the income and capital, nor the operating cost of the organisations regarding the fiscal year, creating exposure to great potential for deliberate manipulation by the executive and management of the Public Sector. Civil society including Transparency International continue to call for government commitment to reforms including Public Financial Management ones to improve transparency and accountability to the people they govern (Transparency International, 2006). The call is rather timely as the cash accounting systems are deemed to allow room for abuse of public resources for personal gains, particularly as it keeps no record of usage, a practice that creates the dreadful lacuna to corruption by Transparency International descriptions. Further, it has been almost a decade since approval for accrual system of accounting was granted as contained in FAR, 2004, and yet, public organisations continue to operate the cash accounting system despite its attendant problems. Beyond provisions in the FAR 2004, government seem to be silent about executing the project of this reform migration. Yet, the continuous use of the cash accounting system leaves new governments to be oblivious to outstanding debts to entities including contractors, consequently leading to huge judgement debts. As a quest, the study seeks to determine whether government push is necessary to affect this financial management reform, and whether same can affect the abuse of the accounting systems. The study in this quest attempts to address the following questions: Does the existing cash accounting system pose challenges and possible financial losses? Can there be a successful Public Financial Management reform without government backing?

\subsubsection{Objectives}

Following these concerns, the study seeks to determine whether there is genuine government commitment to the financial management reform project of replacing cash basis with accrual basis of accounting system. An attempt is made in the study to establish a relationship between Political Willingness to effect the financial management reform of replacing the cash basis accounting system on the one hand, and;

a. the operations of current activities in the Public Sector;

b. effectiveness of the accounting system against fraud and embezzlement in the Public Sector;

c. PSOs implementation commitment to the accrual basis of accounting in the Public Sector.

This empirical study substantiates whether calls to back Public Sector reforms with Political Will is necessary and reveals needed focus areas in making Public Sector financial management reforms successful.

\subsection{Theoretical \& Empirical Literature Review}

\subsubsection{Political Will \& Commitment}

Political Will as adopted from Kpundeh's definition is contextualised in this study as the demonstrated credible intent of political actors to address causes and effects of corruption at a systemic level, without which governments' reform promises would remain mere rhetoric (Kpundeh, year unknown).

A Political Will hierarchical model likened to Abraham Maslow's Hierarchy of Needs orders 5Ps, thus, power(as the least), protection, provision, peace, prosperity and prestige(as the highest) to define utilitarian components that justify the value to countries' infrastructure base, depending on where the Political Will is placed on that structure (Berenger, 2006).

Within the framework of a theory of continued commitment, Montada \& Kals, 1998 posits that Willingness for Continued Commitment (WCC) is a "proxy" for manifest activities, and proposes WCC as an efficient alternative to intention concept (Montada \& Kals, 1998). 
According to Bratman, intentions are strongly consistent relative to beliefs if all such intentions could be put together into overall plan that is consistent with same beliefs (Bratman, 2009).

By the above theories, depending on the element of the 5Ps that governments seek to pursue on the Berenge's Political Will structure, it has a chance of translating reform promises into economic development as long as there is genuine Willingness for Continued Commitment in a manner that marshals all such intentions into a comprehensive and composite plan that is consistent with subsequent actions.

\subsubsection{Accounting Basis}

Zarandi et al (2013) describe Accounting basis as a type of accounting system or policy operated in organisational entities for keeping track of income and expenses (Zarandi, Ghafari, Arab, \& Mozdabadi, 2013). The two main methods employed are the cash basis method and the accrual accounting method. Tudor \& Mutui, 2013 simplifies the distinction between the two methods by attributing the difference mainly to the timing of when transactions are recognised in the accounts, including sales and purchases. Cash accounting essentially reports cash transaction payments and receipts only, such that, non-cash transactions and credit transactions that lead to amounts owed to organisational entities including implementing government are not recorded. Apart from not reflecting credit transactions in the books of accounts until they are paid for, organisations and countries that operate cash basis accounting system do not show fixed assets register with requisite depreciation on public assets with written down values, but would rather expense such assets off in the year of purchase, a recording system called the cash basis.

The Accounting Technicians Scheme of West Africa (ATSWA) ascribes simplicity to cash basis of accounting reporting as they merely account for receipts and payments. Its financial statements are without the technicalities and complications of estimating for depreciation, doubtful debts, or adjusted accruals and prepayments. Further, compliance to cash limits in use of budgeting of resources as a means of facilitating fiscal stewardship in the Public Sector are much enhanced with cash basis of accounting (Accounting Technicians Schemes of West Africa, 2013). In other words, under Cash basis, financial accounts are recorded in the accounts only when cash is received or disbursed and similarly, goods \& services procured are considered to be consumed only when suppliers are paid (United Nations, 1984). In addition, long term assets are not capitalised, thus, leaving accounts with no record of depreciation or amortisation. Also, disbursements always coincides with expenditures, reducing the accounts to nothing more than summarised cash books. Jones and Pendlebury, 1996 explain that, as there are no assets and liabilities, no balance sheets are prepared; no stock adjustments are made; nor fixed assets accounts kept, as accounts are not focused on usage record, but only concerned with cash payments (Jones \& Pendlebury, Public Sector Accounting, 4th ed, 1996).

Accrual basis of accounting counts all financial transactions when orders are made, items delivered, or services provided, regardless of when the receivables are actually received or payments are made (Zarandi, Ghafari, Arab, \& Mozdabadi, 2013).

The Public Sector has traditionally preferred cash based accounting, particularly as it was deemed to be more appropriate and simple for ensuring compliance with rules and regulations, until accrual based accounting began to receive the attention it has today in the Public Sector Financial management system, following the compromise of financial information quality for decision making endured under cash accounting basis (Tiron Tudor \& Mutiu, 2013). In the case of Ghana, GIFMIS in the Public Sector happen to be applying semi-accrual basis of accounting.

\subsubsection{Method of Migrating to Accrual Basis}

In theory, Tudor \& Mutui suggest three options for implementing migration to accrual basis of accounting.

i. Implementing for state, local and all budget users, thus, total implementation;

ii. Implementing for all budget users, but not for state and local budgets

iii. Implementing for all budget users, except for some state treasuries of public finance such as state budget, local budgets, pensions, health fund, etc.

\subsubsection{Diffusing Fraud \& Corruption with Political Will:}

Anti-corruption institutions have often surged that, fraud and corruption aided by lack of Political Will thrives in "darkness", such that, non-availability of information to the public, and/or, inadequate disclosure in what is made available to the public constitute the "darkness" that provides the haven for corruption. Nelson Mandela is referenced to have said that to achieve a global revolution, a world-wide information society must ensure everyone has a stake and can play a part in that process (Berenger, 2006). Berenger's, 2006 study cites Berry, 1996 \& McPhail, 2002 to have concluded that, the first move towards Political Will is to acknowledge that everyone is a member of an interest 
group and is a stakeholder in communication development. The second move is to form a partnership in development and should invest in education and training. By the acknowledgement of these two moves, employing the accrual reform system of accounting with the aim of improving financial disclosures, governments' commitment to the successful implementation of this reform would require the recognition and involvement of stakeholders, including key officials of PSOs in a well programmed manner.

\subsubsection{Empirical Literature on Accrual and Cash Bases Accounting}

An empirical study conducted in the city of Tehran on Accrual-based accounting system versus Cash-based accounting system in municipality organisations concluded that, accrual-based account performs better in terms of reliability, rules and regulations, information quality and quantity, and provides better comparative results, and, is a superior and better method for managing accounting affairs compared to cash accounting (Zarandi, Ghafari, Arab, \& Mozdabadi, 2013).

Another Accrual Accounting reform study conducted in Greek Public hospitals with the aims of exploring, describing and comparing the actual adoption and implementation of accrual financial and cost accounting practices in same facilities observed that, institutional pressures influences management focus on specific aspects of the reforms (Eriotis, Stamatiadis, \& Vasiliou, 2011). Eriotis et al further observed that, organisational and technical resources such as support of consultants, quality of existing IT, educational level of accounting staff, and, specific training support for the reform purposes were influencing factors for success.

On Romanian public accounting practices, Deaconu et al discovered that, accrual accounting was superiorly beneficial to their emerging economy than cash accounting in properly determining fixed assets, liabilities, revenues and costs, allowing certain choices in the financial structure of entities. It was further observed that, the pace of regulatory changes and their application in practice indirectly confirmed the countries orientation on the reform of migrating to IPSAS and accrual accounting (Deaconu, Nistor, \& Filip, 2011). Fixed assets disclosure in financial statements of private sector entities practicing the accrual basis reflect historical cost, accumulated depreciation, and the written down value of each asset.

Again, an empirical quest into the role of accruals and operating cash flows on users' decision on financial statements reveals that, there was a significant difference between accruals and operating cash flow information content in respect of decision making criteria (Araghi \& Attari, 2013).

\subsubsection{Accrual Accounting \& Corporate Governance}

In a study conducted by Jere et al 2003, financial disclosures are more transparent with timelier accrual based reporting in countries with stronger stakeholder protection, which complements corporate governance (Jere, Inder, \& Raynolde, 2003). Jones, 1994 emphasises the relevance of accrual accounting as a tool for improving accountability and stewardship (Jones, 1994).

It is further argued that, accounting systems correctly reflect management systems needs when it connects with tradition, culture, economic and political factors, to the extent that, Public Sector accounting reforms must be complemented by managerial reforms if it is to improve decision making in governance (Blöndal, 2003; Hoque \& Hopper, 1994).

\subsubsection{Financial Framework}

Ghana's Financial Administrative Act No. 654 of 2003 and Financial Administration Regulation of 2004, L.I. 1802 provide the legal basis on authority, while the Accounting Manual and Departmental Accounting Instructions give operational guidelines.

In Ghana, the Financial Administrative Regulations (FAR), 2004 (L.I. 1802, Part VII, 186 requires government accounts to be prepared using the Accrual basis of accounting (Government of Ghana, 2004). Yet, transition from the Cash basis of accounting to the Accrual basis in accordance with FAR, 2004 has not been fully implemented or perhaps not actually commenced at all.

Qualitative and theoretical research on Public Sector accounting reveals that, the primacy of Accrual accounting in providing transparency in both financial and non-financial performance of the Public cannot be overemphasised, particularly as the Cash basis fails to capture relevant and material transactions in the financial statement (Deaconu, Nistor, \& Filip, 2011). The absence of information disclosure happenings between economic events and cash payment or receipt creates a lacuna, where non-cash related economic transactions remain undisclosed until cash is exchanged. The spate of concerns raised on judgement debts in the centre of topical issues in the media and the 
consequent cost to the Nation Ghana, particularly with successive governments claiming no knowledge of debts and obligations incurred by preceding governments is a worry.

\subsubsection{Public Financial Management Reform}

Chile is acknowledged to be the first to have introduced accrual accounting for the Public Sector as early as in the 70s, while it took New Zealand, the next country more than a decade to join suit in 1990. Countries' approach to implementation or adoption of the accrual system of accounting in the Public Sector has varied. While New Zealand approached the change comprehensively, countries including the US approached it piecemeal, with some states rolling on, and yet other countries had only some state owned organisations adopt it (Carpenter \& Feroz, 2001). Today, New Zealand is acknowledged worldwide to have become one of the countries with the most extensive set of accrual accounting disclosures.

Eriotis et al, 2011 cite Cohen, 2007; Lapsley, 1999; Christiaens, 1999 as indicating the need for change of the public accounting system towards accrual basis as being critical, particularly, as the traditional budgetary cash accounting system is perceived as no longer satisfactory, mainly due to its inability to present an accurate financial picture and provide useful and adequate management information that facilitates the much desired effective planning and performance process.

Abstract on a study conducted by Davis, 2010 on the move from cash basis to accrual basis of accounting in the Australian Public Sector (APS) using Habermas' 1976 theory argues that, accrual accounting can be seen to be a device used by different levels of government to combat tendencies for economic, rationality and legitimacy challenges in the interest of betterment of the larger society (Davis, 2010).

Hay and Mikesell, 1974 recommended the use of accrual accounting for governmental units as it provides a better basis for comparison between actual expenditure and revenues and the amounts authorised in the budget approved by the legislative body, and, further enabling the computation of the cost of rendering services (Hay \& Mikesell, 1974).

Another study that looked at the Impact of Accrual Accounting on Public Sector Management in Romania observed a correlation between the pace of regulatory changes and their application in practice as indirectly confirming the orientation of the Romanian standard-setters towards IPSAS and accrual accounting (Deaconu, Nistor, \& Filip, 2011). Same study argues that, the importance and usefulness of accrual accounting is in the efficiency and effectiveness it brings to Public Sector management.

An empirical study that assessed accrual accounting reform in Greek Public Hospitals revealed that, the level of accrual accounting adoption was positively related to IT quality, reform related training, education level of accounting staff, and professional consultants' support (Eriotis, Stamatiadis, \& Vasiliou, 2011).

Even as the move to accrual basis for Public Sector financial reporting has received some positives, it is worth noting that, the support has not been universal, with powerful entities like IFAC, EU commission, and IMF not in agreement, while SIGMA and DFID who work in developing countries, question the need for prioritising the migration to accrual basis of accounting in the Public Sector (Tiron Tudor \& Mutiu, 2013).

The need for detailed disclosures in financial information calls for reporting system that provides the platform for conducting wider financial analysis than the simple budget analysis that the cash basis allows (Tiron Tudor \& Mutiu, 2013). Tudor \& Mutiu add that, there is need to train and develop the skills of both preparers and users of the accrual system's financial information, particularly as skilled accountants employed by the Public Sector are rather few.

The UN recognised that, lack of Political Will inhibits long-term prospects for creating effective structures in governance (Diehl, 2005).

\subsubsection{Reforms}

Successful reform requires strategies for getting around political obstacles to building one, not just a clear view of the mountain peak in the distance, but an ability to find a path to it, which he calls, the "HOW" strategy of reform (Shleifer \& Treisman, 2001). They add that, much as reforms may have transpired successfully or unsuccessfully in authoritarian regimes and democratic ones, multiparty systems and coalition governments have been associated with poor macroeconomic policy, with no clear indication of which governance systems emerging the best. Instead, Shleifer \& Treisman indicate that, recent and growing literature in political economy attributes successful jumps over political hurdles to Reform Sequencing as a means to achieve results. Gerard suggests that, the sequencing of reforms in transition economies are expected to be commenced with popular ones first (Ge'rard, 2002). In the 
educational sector, Deng Xiaoping in China has employed financial reforms as a component part of the process of decentralising public finance, indicative of how such reforms can be on sector basis (Tsang, 1996).

Bratman, 2009 indicates that, intentions and actions should be coordinated in such a way as to follow out a plan, and yet admits that, incompatible or mutually exclusive actions could however be alternatives to accomplishing an intention (Bratman, 2009). He adds that, intentions aid co-ordination of larger plans in a way that exerts pressure towards unification of various intentions (Bratman, 2009).

\subsection{Hypotheses}

\subsubsection{Distortions of True Operations Due To Lack of Political Will To Effect Reform}

Zaranda et al (2013) express the superiority of accrual accounting system in terms of reliability, information quality and quantity, and, its effect on stewardship. Within the context where Cohen, 2007; Lapsley, 1999; Christiaens, 1999 perceive the cash accounting system as unsatisfactory mainly due to its attendant inaccuracies, and yet, the successful implementation of government reforms is suggested by Kpundeh to be dependent on government's own Political Will. The gabs created between the economic events and actual operations by cash basis reporting systems give room for distortions to decision making (Tiron et al, 2013). This translates into projecting that, the lack of Political Will to implement the accrual basis reform would continue to see distortions of the true operation in the Public Sector, thus, the hypothesis:

H1: Lack of Political Will to implement accrual basis of accounting distorts true operations of current activities.

\subsubsection{Transparency effect of Accrual Accounting Reform on Fraud and Embezzlement}

Again, given Kpundeh's arguments that Political Will is the lubrication to effecting governments' reform promises; and that, financial disclosures are more transparent with accrual accounting systems than cash accounting as suggested by Jere et al 2003, with detailed financial disclosures allowing the platform for conducting wider financial analysis as further indicated by Tiron et al 2013; then one would expect that, as Political Will could bring the accrual reform into effect, the transparency afforded by the accrual basis reform should stifle fraud and embezzlement, thus, hypothesis $\mathrm{H} 2$.

H2: Lack of Political Will to effect accrual basis of accounting reform perpetrates fraud and embezzlement.

\subsubsection{Governments' Commitment to Push PSOs into Effecting Reform}

Eriotis et al (2011) observe that, institutional pressures influences management focus on specific aspects of reforms. Gerard, 2002 indicates that, successful jumps over political hurdles are inspired by Reform sequencing, with Bratman, 2009 adding that, intentions and actions should be coordinated to be able to follow the various components of a larger plan towards unified goals. Further, Montada \& Kals, 1998 posits that, Willingness for Continued Commitment is a "proxy" for manifest actions. Together, it suggests that, the commitment of PSOs to the accrual basis reform is dependent on government's commitment to the accrual reform project, executable through a well sequenced larger plan, mapped out to attain the set goal.

H3: PSOs' willingness to replace cash basis of accounting is dependent on governments' commitment to its implementation.

\section{Method}

The study which was conducted in Ghana randomly administered one questionnaire to one Senior Accounts Officer of each Public Service organisation. The Public Service Organisations included some Ministries, Departments and Agencies. Respondents were chosen from the Head Offices of these organisations, as these were more representative of the Ministries, Departments and Agencies. Senior Accounts Officers of public service organisations were chosen as the population as these were persons presumed to understand the technicalities of "accrual basis" and "cash basis" and were more disposed to understanding the effects thereof, on the Public Sector. Only 39 responses was received, representing $67 \%$ response rate. The choice of Ghana for the study was informed by the requirements of the Financial Administrative Regulations (FAR), 2004 (L.I. 1802, Part VII, 186 for government accounts to be prepared using the Accrual basis of accounting (Government of Ghana, 2004), yet most public service organisations continuing to apply the cash basis.

As the enactment of the FAR, 2004 was expected to improve the quality of the Public Financial Management System, the study provided for certain relevant variables by asking respondents questions that would indicate their perspective of the Political Will backing the regulation, the integrity of the prevailing accounting systems, the robustness to fraud \& embezzlements, and commitment of organisations to effecting the implementation of the 
accrual basis of accounting. As a way of keeping the instrument simple bearing in mind, the need to attract high response rates, most questions were closed ended with Likert scale (i.e. Strongly Agree, Agree, Don't Know, Disagree and Strongly Disagree), with few instances requiring explanations.

Until the recent GIFMIS efforts, not much work have been done on the Public Financial Management System of Ghana, more so on the Accounting basis employed by Ghana and their attendant effects. Following that responses to the variables were nominal in nature, Pearson's chi squared tabular model was intended for the analysis, but as the response rate was less than 40 , the study turned to fisher exact model, which is designated for smaller data sets and was conducted using STATA 12, a statistical software.

The study based on Accounts Personnel's perspectives provides their perception about Political Will which could differ from the reality; it is believed that, accountants are entitled to such perceptions to inform their professional actions. Further, accountants have a better understanding of implications of employing one accounting system from the other and are more disposed to providing a better picture of the situation.

\section{Results and Discussions}

\subsection{Political Will to Reform \& Integrity of Cash Basis}

An analysis of table 1 that addresses hypothesis H1, thus, Lack of Political Will to implement accrual basis of accounting distorts true operations of current activities, showed a statistical significance of 0.00 , indicative that, lack of Political Will to implement accrual basis of accounting has a relationship with continued distortions of true operations of current activities in the Public Sector. This finding justifies Jones \& Pendlebury's 1996 claim that, the cash basis does not keep focus on usage record but only concerns itself with only cash payments, thus creating a potential gap that distorts effective management of "MEANS" from which "the DESIRED END" are attained. It also points to the compromised quality of financial management decision making endured in Ghana's Public Sector given the cash accounting systems in use, in consistency with Araghi \& Attari's, 2013 findings. No assets, no liabilities, no balance sheet, no stock adjustments, no fixed assets accounts. How therefore can management of operations be true if the existence of these are true and yet, treated as though they were not. Taking cue from Jere et al 2003 \& Jones 1994, the finding suggests that, if Public Sector accounting systems is to be abated of distortions and to reflect improved financial disclosure, accountability and stewardship as required, governments' commitment to implementation of the accrual basis, a more transparent financial management system should be pursued vigorously. Employing Kpundeh's theory, the continued fraud and embezzlement with impunity in the Public Sector in spite of policy reforms on paper (not being implemented) to avert such malfeasance questions the credibility of the intentions of political actors.

Table 1. Political Will to Reform \& Integrity of Cash Basis

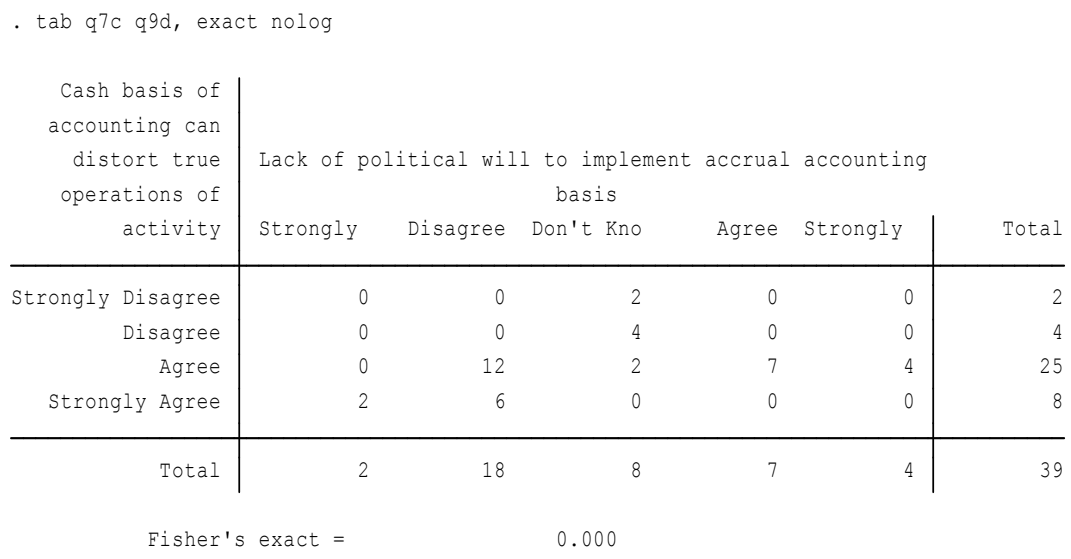

\subsection{Political Will to Reform and Fighting Fraud \& Embezzlement in Cash Basis}

Table 2 that tests hypothesis $\mathrm{H} 2$ indicates a statistical significance between Fraud \& embezzlement in cash basis of accounting and, the lack of Political Will to implement accrual accounting systems. In other words, as the government lacks the will to implement an effective accrual accounting system, it fails to rid the Public Sector of the rot of fraud and embezzlement as the current cash accounting system continue to be rife with these. This is consistent with UN's observation of how lack of Political Will inhibits prospects for creating effective structures in governance (Diehl, 2005). Further, governments' commitment to instituting measures that serve the betterment of the general public is brought into question as this posture of not committing to the accrual accounting reform is manifest in 
combating economic challenges as suggested by Davis, 2010. Given the prevailing fraud and embezzlements endured in the cash accounting system in the Public Sector, Jones', 1994 emphasis on the relevance of accrual accounting as a tool for improving accountability and stewardship cannot be overemphasised (Jones, 1994).

Table 2. Political Will to Reform \& Fighting Fraud and Embezzlement

\begin{tabular}{|c|c|c|c|c|c|c|}
\hline $\begin{array}{r}\text { Cash basis of } \\
\text { accounting } \\
\text { contributes } \\
\text { significantly to } \\
\text { fraud \& } \\
\text { embezzlemt in PSO }\end{array}$ & $\begin{array}{l}\text { Lack of } p \\
\text { Strongly }\end{array}$ & $\begin{array}{l}\text { itical wi } \\
\text { Disagree }\end{array}$ & $\begin{array}{l}\text { I to implem } \\
\text { basis } \\
\text { Don't Kno }\end{array}$ & $\begin{array}{l}\text { accrual } \\
\text { Agree }\end{array}$ & $\begin{array}{l}\text { accounting } \\
\text { Strongly }\end{array}$ & Total \\
\hline Strongly Disagree & 0 & 2 & 2 & 0 & 0 & 4 \\
\hline Disagree & 0 & 8 & 6 & 0 & 2 & 16 \\
\hline Don't know & 0 & 2 & 0 & 7 & 2 & 11 \\
\hline Agree & 0 & 6 & 0 & 0 & 0 & 6 \\
\hline Strongly Agree & 2 & 0 & 0 & 0 & 0 & 2 \\
\hline Total & 2 & 18 & 8 & 7 & 4 & 39 \\
\hline
\end{tabular}

\subsection{PSOs' Commitment to Accrual Basis Reform \& Political Will to Reform}

Analysis in Table 3 on hypothesis H3 shows statistical significance, as it reveals that, the PSOs are committed to replacing the cash basis with the accrual basis of accounting to the extent that it is backed by Political Will. Indicative from the absence of a clear migration plan as suggested in theory by Tudor \& Mutui, 2013 and, the absence of an overall plan consistent with the said reforms as suggested by Bratman, 2009, PSOs' lackadaicity to implementing the accrual basis of accounting reform is attributable to lack of Political Will to exact the reform project. Also, it indicates that, the non-implementation of the accrual basis project is more politically blameable than professionally blameable.

Table 3. PSOs' Commitment to Reform \& Political Will to Reform

\begin{tabular}{|c|c|c|c|c|c|c|}
\hline \multirow{2}{*}{$\begin{array}{r}\text { Implementation of } \\
\text { accrual basis in } \\
\text { replacement of } \\
\text { cash basis is not } \\
\text { mandatory }\end{array}$} & \multicolumn{6}{|c|}{$\begin{array}{c}\text { Lack of political will to implement accrual accounting } \\
\text { basis }\end{array}$} \\
\hline & Strongly & Disagree & Don't Kno & Agree & Strongly & Total \\
\hline Strongly Disagree & 2 & 2 & 2 & 0 & 0 & 6 \\
\hline Disagree & 0 & 4 & 6 & 0 & 4 & 14 \\
\hline Don't know & 0 & 2 & 0 & 0 & 0 & 2 \\
\hline Agree & 0 & 2 & 0 & 7 & 0 & 9 \\
\hline Strongly Agree & 0 & 6 & 0 & 0 & 0 & 6 \\
\hline Total & 2 & 16 & 8 & 7 & 4 & 37 \\
\hline Fisher' & exact $=$ & & 0.000 & & & \\
\hline
\end{tabular}

\section{Conclusions \& Recommendations}

\subsection{Conclusions}

The cash accounting systems has distortions not reflective of the true activities or operation of the PSOs. The cash accounting system is vulnerable to financial abuse, fraud, embezzlement and malfeasance. The accrual accounting system is a superior system of accounting to providing sufficient and relevant information for decision making. The delay in the implementation of the accrual basis of accounting reform in the Public Sector means delay in quality decision making in the Public Sector as information used for decision making have distortions. The delayed implementation of the accrual accounting system by PSO is partly attributable to lack of governments' commitment to the call for its implementation. The commitment of PSOs to replacing cash basis with accrual basis of accounting is dependent on the Political Will backing the policy to the reform. 


\subsection{Value Added}

The cash basis of accounting in the Public Sector is susceptible to fraud and embezzlement. Reforms that bring effective changes to Public Service accounting systems require Political Will. The Accrual basis of accounting reform has the propensity of curbing fraud and embezzlement suffered under the cash accounting system. The accrual basis of accounting systems when effected would improve quality of financial management decisions in the Public Sector. Also, PSOs are responsive to reform implementations when Political Will is demonstrated.

\subsection{Recommendation}

To demonstrate Political Willingness, there is need to determine the scope and content for the implementation of the accrual basis of accounting nationwide, and, a clear premise for determining the book value of assets among other things so as to ensure implementation uniformity across the Public Sector where possible.

Also, government must roll out a clear planned schedule with time lines or ultimatums for PSO, by which implementation should be effected, an approach that would firm up government's grips over the efficient management of the implementation process. Particularly as costs would necessarily be involved in such reforms, government could strategize on implementation modalities by defining entities or sectors that must join as per predetermined schedules. Training programme should be organised for personnel to understand the implication of the accrual basis and the possible changes that would occur with its introduction for effective implementation.

For successful implementation of the reform, it is further recommended that, government complements its qualified accountants with accounting technicians, and collaborates with the ICAG to make up for capacity shortfalls (to produce \& retrain accounting technicians) as the use of the accrual accounting system requires more skills than required of the cash basis.

\section{Acknowledgement}

I wish to acknowledge Saviour Adjei and Asare Nyarko Rhoda for the support they provided in gathering the relevant data.

\section{References}

Accounting Technicians Schemes of West Africa. (2013, Sept). Public Sector Accounting Study Pack. Retrieved from Accounting Technicians of Schemes Africa: www.icanig.org/documents/ATSWA_PUBLIC_SECTOR_ACCOUNTING.pdf

Araghi, M. S., \& Attari, S. (2013). Comparing the role of accrual and operating cashflows on users' decision on financial statements: A study of Tehran Stock Exchange. Management Science Letters 3, 97-106. http://dx.doi.org/10.5267/j.msl.2012.12.029.

Berenger, R. D. (2006). Political Will and Closing the Digital Divide. GMJ, Edition 1(1), 56-70.

Blöndal, J. (2003). 'Budget Reform in OECD Member Countries: Common Trends'. OECD Journal of Budgeting, Vol.2, no 4, 7-25. http://dx.doi.org/10.1787/budget-v2-art20-en

Boateng, I. (2008, March 26). Employment and Labour- Ghana. Retrieved from International Law Office: http://www.internationallawoffice.com/newsletters

Bratman, M. E. (2009, September 5). Davidson's Theory of Intention. In Faces of Intention: Selected Essays on Intention and Agency (pp. 209-224). Cambridge University Press. Retrieved from UMN.EDU: http://www.tc.umn.edu/ pwhanks/teaching/teaching/4008/bratman.pdf

Carpenter, V., \& Feroz, E. (2001). Institutional theory and accounting rule choic: an analysis of four US state governments' decision to adopt generally accepted accounting principles. Accounting, Organisations \& Society, 26, 565-596. http://dx.doi.org/10.1016/S0361-3682(00)00038-6

Davis, N. (2010). Accrual Accounting and the Australian Public Sector- A Legitimation Explanation. Australasian Accounting Business and Finance Journal, 4(2), 61-78.

Deaconu, A., Nistor, C. S., \& Filip, C. (2011). The Impact of Accrual Accounting on Public Sector Management. An exploratory study for Romania. Transylvanian Review of Administrative Sciences, No. 32 E, 74-97.

Diehl, P. F. (2005). The Politics of Global Governance: International Organisations in an Interdependent World. Boulder: Lynne Rienner Publishers.

Eriotis, N., Stamatiadis, F., \& Vasiliou, D. (2011). Assessing Accrual Accounting Reform in Greek Public Hospital: An Empirical Investigation. International Journal of Economic Sciences and Applied Research, 4(1), 153-183. 
Ge'rard, R. (2002). The Political Economy of Transition. Journal of Economic Perspectives-Volume 16, Number 1, 29-50. http://dx.doi.org/10.1257/0895330027102.

Gilbert, M. (2007). A Theory of Political Obligation: Membership, Commitment, and the Bonds of Society. Mind, Vol.116, 1126-1129. http://dx.doi.org/10.1093/mind/fzm1126

Government of Ghana. (2004). Financial Administration Regulation of 2004, L.I. 1802, Part VII, 186. Accra: Government of Ghana.

Hay, L. E., \& Mikesell, R. (1974). Governmental Accounting. Homewood Illinois: Richard D Irwin Inc.

His Excellency Mahama, J. D. (2013). Corruption in Africa. Accra: Universal TV.

Hoque, Z., \& Hopper, T. (1994). Rationality, Accouting and Politics: A case study of Management Control in a Bangladesh Jute Mills. Management Accounting Research, Vol. 5, No. 1, 5-30. http://dx.doi.org/10.1006/mare.1994.1002

ICAEW. (2012, October). Audit Quality-Our key findigs-Going Concern. Audit Monitoring 2012, pp. 05-09.

Jere, R. F., Inder, K. K., \& Raynolde, P. (2003). The role of accountingand auditing in corporate governance and the development of financial markets around the world. Asia-Pacific Journal of Accounting \& Economics, Vol 10, Issue1, 1-30.

Jones, R. (1994). On the Publication of Accounts. The British Accounting Association Annual Conference. Winchester.

Jones, R., \& Pendlebury, M. (1996). Public Sector Accounting, 4th ed. London: Pitman Publishing.

Kpundeh, S. J. (year unknown). Political Will in Fighting Corruption. Corruption \& Integrity Improvement Initiatives in Developing Countries, 91-110.

Lowenstein, L. (2013, September). Financial Transparency and Corporate Governance: You manage what you measure. $\quad$ Retrieved from Heinonline: http://heinonline.org/HOL/LandingPage?collection=journals\&handle=hein.journals/clr96\&div=47\&id=\&page=

Montada, L., \& Kals, E. (1998). A theory of willingness for continued responsible commitment. Retrieved from http://psydok.sulb.uni-saarland.de/volltexte/2007/922/pdf/beri114.pdf

Shleifer, A., \& Treisman, D. (2001). Without a Map: Political Tactics and Economic Reform in Russia. Massachusette: The Massachusette Institute of Technology Press.

Tiron Tudor, A., \& Mutiu, A. (2013, September). Cash Versus Accrual Accounting in Public Sector. Retrieved from http://ssrn.com/abstract=906813

Transparency International. (2006). Anti-Corruption Conventions in Africa. Berlin: Transparency International.

Transparency International. (2013). Transparency International. Retrieved from Pillars of National Integrity: http://www.transparency.org/whatwedo/nis

Tsang, M. C. (1996). Financial Reform of Basic Education in China. Economics of Education Review, Vol. 15, No.4, 423-444. http://dx.doi.org/10.1016/S0272-7757(96)00016-7

United Nations. (1984). Manual for Government Accounting: Accrual Accounting in Developing Countries. New York: Department of Technical Cooperation for Development.

Zarandi, H. M., Ghafari, E., Arab, M., \& Mozdabadi, S. M. (2013). Accrual-based Accounting system versus Cash-based accounting; An empirical study in municipality organisation. Management Science Letters 3, 251-256. http://dx.doi.org/10.5267/j.msl.2012.10.035 